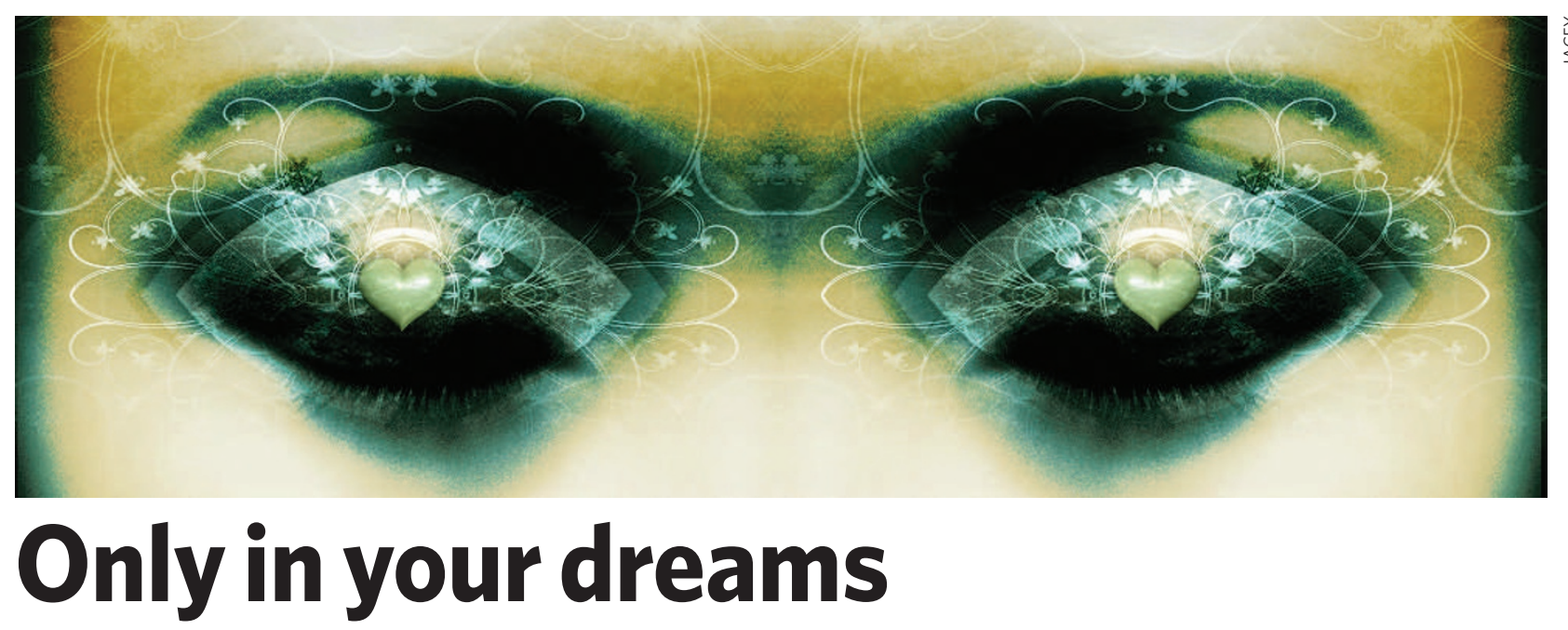

It's a wonderful life.

\section{Arran Frood}

I'll miss this place. Clinical as it is, I've grown attached to how it makes me feel. I'm one of the stars, the brightest even, and this place makes me feel like I'm special. Maybe I am.

I won't miss the journey, the menacing building or the totalitarian security. I'll miss what it has become - the most wonderful personal adventure. It's not just a trial; it's an exploration of the nature of consciousness. Or is it the unconscious? Both, probably.

"I didn't think you were awake," says $\mathrm{Mr}$ Wonderful - another reason I'll miss this place - as he checks a bank of screens, keying in numbers until the machines hum in placid agreement. He looks very happy today.

"Oh I was just thinking about...the dreams...you know, and stuff,' I reply. Best keep it casual. Don't give anything away, even though Mr Subject Liaison Officer will never know.

"What kind of stuff? About leaving?" We both know it's my last day. That's cute. He's so nice! I tell him I'm fine.

"Lie down then, and we'll get your last session sorted."

The routine begins - for the final time I close my eyes and picture him last night.

"You know, you've really been a star around here," he continues, mindless to the real action. "You've pushed the project on like no one else has. Past the limits of what we, or they, thought was possible. It's just amazing."

He's right. I have been an excellent subject. I can tell from their faces; not just the professors, but everyone, that I'm important, cherished. And all I do is dream.

When I responded to the advertisement, I never thought it would go this far. Lucid dreamers wanted. Women of any age, Taurus, who had never taken drugs. Check, check, check. Sleep and get paid? You're on.
Divulge details of dreams in finest detail? A small price to pay for the money on offer.

That was seven years ago. Now the tests are faster, the corridors longer and the cheques larger. When I saw the first hazy, bitmapped images it was like seeing a part of myself that I always knew was there but was seen only by saints or devils. My dreams laid bare for the Readers.

It was two years before I even knew what was really going on. Symbols and diagrams to meditate on before a sleep; then objects, people and places; and now entire scenarios and plays. All before a reimagining with the Readers, so they could hone the technology that would read the dream from my nightly secretions.

"Relax. Perfect. I'm taking the pads off now," says Mr Wonderful. I'll miss the deference he shows each time he does the routine, like now, as I feel him gently peel away the tissues from my naked body. We never speak at this point. I feel him finish and open half an eye to see him securing my dreams in a sterile box like a genie in a lamp. A dreamie, even.

Mr Wonderful: you are a wonderful lover - a fair prince in this palace of plastic - even if I do make it all happen. I admit it will be embarrassing to recall and verify with my Reader (not for the first time) but she can keep a secret - my specialness has earned me a little leeway.

I am a Lucid 5. The first one, in fact, although I understand there are others. I don't know how it's done; I don't think they really do, but it will be a revelation - a revolution even - when it is finally unleashed upon the world.

I don't know the whole story, they can't tell me, but you hear things. For more than a century people knew the body produced natural hallucinogens in the tiniest amounts, but no one had looked at them. No one imagined they tuned our body clocks until migraine and something else
- cluster headache? - were cured all those years ago. That was the key. Our biorhythms, REM sleep, all dancing to the tune of a tiny gland barely even in the brain. Telepathy, déjà vu, the sixth sense... whatever you call it. Everything answered at a stroke. And they got there through the dreams. My dreams.

"Right. That's you done. Hello?"

Mr Wonderful's work is finished.

"Is that a wrap then?" I say.

"That's a wrap!" We both smile. The old ones are best.

"Wow. That's your last one. Historic, really. What was last night, a free dream wasn't it?"

"Yes it was a free dream," I say, and bite my lip. A little too free probably, but it was fun while it lasted. He's looking so pleased today. I ask why, and as soon as he speaks I wish I hadn't.

"Well, I shouldn't say anything but... well, since you're leaving... I got promoted!"

What?! Oh my God!

"I haven't signed yet, but the person who matters says it's a cert."

No, no, no, no. Please, no.

"I've passed the exams, and psychoaptitude runs. This is it - I'm finally going to be a Reader."

I can't speak. That means he'll be able to see...

"It means I'll have access to the archives, your dreams, all the work we did together - everything."

Heart. Thump. Mouth. Dry. Head. Spin.

"You know it probably helped. Working with you, I mean. So...erm... well, thanks!"

"Brilliant!" I squeak.

My eyes are watering.

"There's a long way to go of course but, well, one day I'll learn to see it all."

And you will Mr Wonderful, you will. Arran Frood is a freelance science and science-fiction writer based in London. 